\title{
Early intensification and autologous stem cell transplantation in patients with systemic AL amyloidosis: a single-centre experience
}

\author{
Valérie Frossard • Nicolas Ketterer • Anne Rosselet • \\ Pascal Meier • Anne Cairoli • Michel A. Duchosal • \\ Tibor Kovacsovics
}

Received: 20 August 2008 / Accepted: 20 November 2008 /Published online: 6 December 2008

(C) Springer-Verlag 2008

\begin{abstract}
Primary systemic amyloidosis (AL amyloidosis) continues to have a very poor prognosis. Most therapeutic strategies remain unsatisfactory. Conventional chemotherapy is known to offer at best only moderate efficacy. Several studies have yielded higher complete response rates after high-dose chemotherapy and autologous stem cell transplantation (ASCT) in addition to improving outcomes in a subgroup of patients. However, the superiority of an intensive approach in $\mathrm{AL}$ amyloidosis has not been confirmed in a randomised trial. The precise role of ASCT remains unclear. We report our experience in 16 patients diagnosed with $\mathrm{AL}$ amyloidosis and treated in a multidisciplinary approach with high-dose melphalan and ASCT. Median age was 59 (3971 ) years. The kidneys were predominantly affected in $75 \%$ of cases; two or more organs were affected in $38 \%$. Median time from diagnosis to transplantation was $2(1-4)$ months. Three patients $(19 \%)$ developed acute renal failure and required transient dialysis. Transplant-related mortality was $6 \%$ after 100 days. Haematological complete response (CR) was
\end{abstract}

\footnotetext{
V. Frossard · A. Rosselet · A. Cairoli · M. A. Duchosal •

T. Kovacsovics

Department of Haematology, University Hospital CHUV,

Lausanne, Switzerland

N. Ketterer

Department of Oncology, University Hospital CHUV,

Lausanne, Switzerland

P. Meier

Department of Nephrology, University Hospital CHUV,

Lausanne, Switzerland

N. Ketterer $(\bowtie)$

Multidisciplinary Oncology Centre, CHUV,

BH-06,

1011 Lausanne, Switzerland

e-mail: Nicolas.Ketterer@chuv.ch
}

obtained in nine (56\%) and organ response in six (38\%) patients. Nine out of 12 patients (75\%) with kidney involvement exhibited a sustained clinical benefit at 12 months. Half of all the patients $(n=8)$ were alive after a median follow-up of 33 months, including two in continuous CR. This suggests that high-dose chemotherapy and ASCT are still valid treatment options in $\mathrm{AL}$ amyloidosis and that a significant number of patients with renal involvement might benefit from this approach.

Keywords AL amyloidosis · Chemotherapy .

Autologous stem cell transplantation

\section{Introduction}

Primary systemic amyloidosis (AL amyloidosis) is a rare clonal plasma cell disorder whose prognosis has been dismal due to widespread organ involvement and a limited range of available therapeutic options. Conventional chemotherapy with oral melphalan combined with prednisone has long been the standard treatment, with less than $25 \%$ response rates and a rather modest effect on survival [1]. Several studies have recently shown that high-dose melphalan followed by autologous stem cell transplantation (ASCT) could yield a high rate of complete responders $[2,3]$ in addition to improving long-term outcomes among selected patients [4-6]. The same intensive approach was also shown to improve substantially both the performance status and the quality of life of good responders [7, 8].

However, the benefit of ASCT in the treatment of AL amyloidosis remains debatable. A multicentric randomised trial failed to confirm the superiority of an intensive to a standard approach [9]. An important limiting factor is transplant-related mortality (TRM), as the rate of around 
$13 \%$ obtained in expert centres might be considerably higher in less-experienced hands [4, 5]. Recent findings have shown a large potential improvement of patients' outcome by optimising clinical management in the perioperative course of ASCT and by adopting a risk-adapted approach $[2,10]$. The present study illustrates our longitudinal experience with early intensification in AL amyloidosis based on 16 patients treated at a single centre.

\section{Study design}

A total of 16 patients with advanced systemic AL amyloidosis were selected for treatment with high-dose melphalan followed by ASCT at our centre between 1997 and 2005. All patients had biopsy-proven amyloidosis and evidence of plasma cell dyscrasia. Visceral involvement was diagnosed as outlined by the International Consensus Opinion [11]. All patients were enrolled in our institutional ASCT programme and gave their written informed consent in accordance with the Declaration of Helsinki. The analysis of this series was performed according to quality assessment by general authorisation of the local Ethics Committee.

The decision to perform intensive therapy was reached on the basis of specific multidisciplinary assessments including specialised renal and cardiac examinations. Neurological evaluation was performed when appropriate. Peripheral stem cells were mobilised using either granulocyte-colony-stimulating factor (G-CSF) or cyclophosphamide $+\mathrm{G}-\mathrm{CSF}$. Subsequently a conditioning regimen of melphalan 140 or $200 \mathrm{mg} / \mathrm{m}^{2}$ was administered. Patients with both renal and extra-renal disease were treated in the intensive care unit. All patients received multidisciplinary care throughout the hospitalisation period, including daily evaluations by a nephrologist.

Response was analysed 100 days after transplantation according to the International Consensus Opinion [11]. Free light chains measurement not being available in all cases, patients with negative immunofixation in serum and urine and with $<5 \%$ plasma cells in BM were considered in haematological CR. TRM was assessed 3 months after transplant.

\section{Results}

Patient data are listed in Table 1 and their clinical parameters in Table 2. Median age was 59 (39-71) years. Kidneys were involved as the predominant organ in 12 out of 16 cases $(75 \%)$. Two or more organs were infiltrated in six cases $(38 \%)$. Median time from diagnosis to transplantation was $2(1-4)$ months. A median of $5.05 \times 10^{6} \mathrm{CD} 34^{+}$ cells $/ \mathrm{kg}$ (range, $2.5-11.7 \times 10^{6}$ ) was administered. Patients were hospitalised for a median of 26 (13-67) days.
Table 1 Patient characteristics at baseline

Patient characteristics

\begin{tabular}{ll}
\hline No. of patients & 16 \\
Median age (years) & $59(39-71)$ \\
Male/female & $8 / 8$ \\
ECOG performance status (median) & $2(1-3)$ \\
Monoclonal gammapathy (No.) & \\
Lambda & 15 \\
Kappa & 1 \\
Proteinuria (median g/l) & $6(0.08-26.8)$ \\
Serum albumin (median g/dl) & $26(15-43)$ \\
Serum creatinine (median $\mu$ mol/l) & $78(38-208)$ \\
Creatinine clearance evaluation (median ml/min) & $72(35-154)$ \\
Serum alkaline phosphatase (median U/l) & $103(53-712)$ \\
Major organs involved (median no.) $)^{\mathrm{c}}$ & $1(1-3)$ \\
No. of patients with $\geq 2$ organs involved & 6 \\
Left ventricular ejection fraction (median $\%)$ & $60(30-88)$ \\
Time from diagnosis to transplantation & $2(1-4)$ \\
(median months) & \\
Mobilisation (No.) & \\
G-CSF & 15 \\
Cyclophosphamide+G-CSF & 1 \\
Conditioning regimen (No.) & \\
Melphalan $140 \mathrm{mg} / \mathrm{m}^{2}$ & 4 \\
Melphalan $200 \mathrm{mg} / \mathrm{m}^{2}$ & 12
\end{tabular}

${ }^{\text {a }}$ Data on 15 patients only

${ }^{\mathrm{b}}$ Cockcroft-Gault

${ }^{\mathrm{c}}$ Including kidney, heart, nerves or liver only

Most treatments were performed in the intensive care unit, but patients with purely renal involvement $(n=7)$ were treated in the transplantation unit with close renal monitoring. Of the 12 patients with predominantly renal involvement, three developed acute renal failure requiring initiation of dialysis. Renal function swiftly recovered in two of them during hospitalisation; in the third case, dialysis could be discontinued 3 months after transplantation.

One 70-year-old patient (\#7) died from sepsis and multiorgan failure on day 11 after transplantation. No other deaths occurred within 100 days of treatment. Thus the rate of TRM was $6 \%$. Nine patients $(56 \%)$ showed haematological $\mathrm{CR}$ and remained complete responders for a median of 31 (8-97) months. Organ response was obtained in six patients (38\%; Table 2).

Of the 12 patients with kidney involvement, a total of four (33\%) met the criteria for renal response at 12 months and five $(42 \%)$ exhibited prolonged stabilisation of renal function. Thus the overall rate of sustained clinical benefit was $75 \%$. Fourteen of the 16 patients survived longer than 1 year. A total of eight patients died after a median follow-up period of 33 months, including one who was progression-free and who died 55 months following transplantation. Eight patients $(50 \%)$ survived (Fig. 1). Two survivors continuously showed CR after 82 and 97 months respectively. 
Table 2 Clinical manifestations (at the time of autologous stem cell transplantation) and outcomes

\begin{tabular}{|c|c|c|c|c|c|c|c|c|c|}
\hline Patient & Age & $\begin{array}{l}\text { Predominant } \\
\text { organ } \\
\text { involved }\end{array}$ & $\begin{array}{l}\text { Other } \\
\text { organs } \\
\text { involved }\end{array}$ & $\begin{array}{l}\text { Time from } \\
\text { diagnosis to } \\
\text { transplantation }\end{array}$ & $\begin{array}{l}\text { Haematological } \\
\text { response at } \\
3 \text { months }\end{array}$ & $\begin{array}{l}\text { Duration of } \\
\text { haematological } \\
\text { complete } \\
\text { response }\end{array}$ & $\begin{array}{l}\text { Organ } \\
\text { response at } \\
12 \text { months }\end{array}$ & $\begin{array}{l}\text { Survival } \\
\text { (months) }\end{array}$ & $\begin{array}{l}\text { Cause } \\
\text { of death }\end{array}$ \\
\hline 1 & 61 & Kidney & ST & $2 \mathrm{~m}$ & $\mathrm{CR}$ & 55 & + & Died at +55 & $\begin{array}{l}\text { Sepsis, } \\
\text { arrhythmia }\end{array}$ \\
\hline 2 & 39 & Heart & $\mathrm{G}, \mathrm{ST}, \mathrm{LN}$ & $3 \mathrm{~m}$ & $\mathrm{CR}$ & 55 & + & Died at +57 & Progression \\
\hline 3 & 60 & Kidney & $\mathrm{H}, \mathrm{ST}$ & $1 \mathrm{~m}$ & $\mathrm{CR}$ & 97 & + & Alive at +97 & \\
\hline 4 & 71 & Heart & & $2 \mathrm{~m}$ & $\mathrm{CR}$ & 13 & + & Died at +58 & $\begin{array}{c}\text { Sudden } \\
\text { death }\end{array}$ \\
\hline 5 & 67 & Liver & $\mathrm{K}, \mathrm{LN}$ & $2 \mathrm{~m}$ & ND & & NA & Died at +5 & Progression \\
\hline 6 & 56 & Neuropathy & $\mathrm{G}, \mathrm{ST}$ & $2 \mathrm{~m}$ & $\mathrm{CR}$ & 82 & SD & Alive at +82 & \\
\hline 7 & 70 & Kidney & & $2 \mathrm{~m}$ & NA & & NA & Died at +0.5 & TRM \\
\hline 8 & 41 & Kidney & $\mathrm{N}$ & $1 \mathrm{~m}$ & $\mathrm{CR}$ & $8^{\mathrm{a}}$ & SD & Alive at +55 & \\
\hline 9 & 62 & Kidney & $\mathrm{H}, \mathrm{N}, \mathrm{ST}$ & $3 \mathrm{~m}$ & $\mathrm{CR}$ & 23 & SD & Died at +31 & Progression \\
\hline 10 & 58 & Kidney & & $3 \mathrm{~m}$ & PR & & + & Alive at +34 & \\
\hline 11 & 50 & Kidney & $\mathrm{H}$ & $3 \mathrm{~m}$ & $\mathrm{CR}$ & $10^{\mathrm{a}}$ & SD & Alive at +49 & \\
\hline 12 & 55 & Kidney & & $2 \mathrm{~m}$ & SD & & SD & Alive at +25 & \\
\hline 13 & 67 & Kidney & & $4 \mathrm{~m}$ & $\mathrm{PD}$ & & $\mathrm{PD}$ & Died at +18 & Progression \\
\hline 14 & 57 & Kidney & $\mathrm{N}$ & $2 \mathrm{~m}$ & ND & & SD & Alive at +25 & \\
\hline 15 & 66 & Kidney & & $3 \mathrm{~m}$ & $\mathrm{CR}$ & 31 & + & Died at +53 & Progression \\
\hline 16 & 39 & Kidney & & $4 \mathrm{~m}$ & SD & & PD & Alive at +15 & \\
\hline
\end{tabular}

Abbreviations: $C R$ complete response, $G$ gut, $H$ heart, $K$ kidney, $L$ liver, $L N$ lymph nodes, $N$ neuropathy, $N D$ not done, $P D$ progressive disease, PSCT peripheral stem cell transplantation, $S D$ stable disease, $S T$ soft tissue, TRM treatment-related mortality

${ }^{\mathrm{a}}$ Second ongoing CR following high-dose dexamethasone

\section{Discussion}

The present series has yielded encouraging results in 16 patients with AL amyloidosis treated by high-dose melphalan chemotherapy and ASCT. A 6\% rate of TRM observed on day 100 after transplantation compares favourably with the findings of other trials $[4,5,12]$. A meta-analysis of single-centre trials (covering 10 to 30 intensified patients each) yielded an average TRM of $21 \%$ [2] and a $13 \%$ rate of TRM has been reported in expert centres $[4,5]$. More

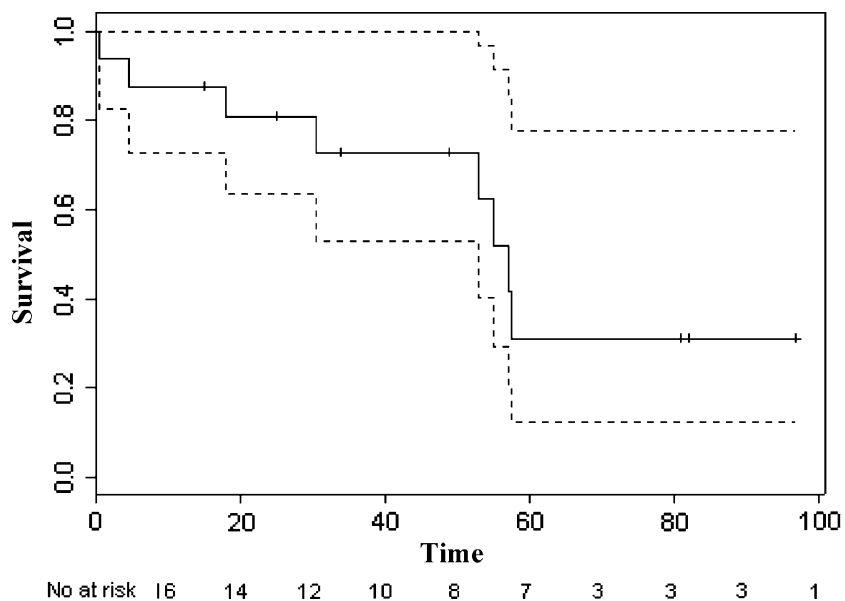

Fig. 1 Overall survival time after months post ASCT recently, Cohen et al. described a TRM of $4.4 \%$ using a risk-adapted approach [10].

We do not believe that our results have been influenced by selecting patients with a good prognosis. Their median age was 59 years while most other series included patients aged between 48 and 55 [8, 13]. One-third of our patients were over 65 . While a risk-adapted approach is generally taken today and is well-acknowledged to offer better results, our series covers a time span large enough for this approach not to have been generally used $[2,14]$. Most of our patients were treated with melphalan $200 \mathrm{mg} / \mathrm{m}^{2}$ as the conditioning regimen despite their generally advanced age and despite involvement of two or more organs in several cases.

Overall toxicity was manageable. Transient acute renal failure occurred in $25 \%$ of cases, which is consistent with previous reports [15]. Haematological complete response and organ response were observed in $56 \%$ and $38 \%$ of patients respectively. The identification of a correlation between organ response and haematological complete response is consistent with previous studies [16]. It is interesting to note that $75 \%$ of patients showed stabilisation of renal function and clinical improvement without meeting the criteria of organ response.

Several factors may explain the encouraging findings obtained in this small retrospective series. Single-centre trials have been known to involve lower rates of TRM than 
multicentric trials $[2,10]$. The time from diagnosis to transplantation (median of 2 months) was well below the range of 4 to 16 months documented in other studies $[8,13]$. The median time from harvesting peripheral stem cells to transplantation was only 11 days. This would support the notion that the delay due to induction treatment before highdose therapy might compromise survival in high-risk patients, particularly in the case of cardiac involvement [17].

The question of optimal timing for high-dose melphalan in $\mathrm{AL}$ amyloidosis remains debatable following reports on a negative impact of early intensification [12]. This effect may have been due to selection of high-risk patients requiring urgent treatment. We hypothesize that most of our patients would not have benefited from frontline chemotherapy, given their advanced age, and that early intensification may have contributed to their favourable outcomes. Moreover, multidisciplinary management was initiated at an early stage and most of the patients were intensified in the intensive care unit. Owing to this specialised management, four patients had a favourable outcome after transplantation despite experiencing grade 3/4 non-haematological toxicities involving $\geq 3$ systems. Other authors have emphasised the importance of careful peri-transplantation evaluation and the need for highly specialised management provided by a well-trained team [2].

Our findings indicate that early treatment with high-dose melphalan may reverse the course of AL amyloidosis and might improve outcomes in a subset of patients, although a randomised trial has failed to confirm superiority of ASCT [9]. Benefits might be confined to a minority of patients treated in tertiary referral centres. We expect that new biomarkers predictive of toxicity and response will be introduced to facilitate patient selection for ASCT [13, 18, 19]. Moreover, the combination of biological agents with ASCT might improve results following an intensive approach [10]. Also, there is a pressing need for other effective treatment modalities in patients too sick for intensive therapy. Preliminary studies on bortezomib or immunomodulatory agents have yielded promising results [20]. Thalidomide combined with dexamethasone or chemotherapy has demonstrated significant efficacy [21]. Preliminary results demonstrating that lenalidomide also has good efficacy and a vastly better toxicity profile are promising and warrant further studies [22, 23]. The available evidence calls for larger studies to define more accurately the role of ASCT in AL amyloidosis.

\section{References}

1. Kyle RA, Gertz MA, Greipp PR, Witzig TE, Lust JA, Lacy MQ, Therneau TM (1997) A trial of three regimens for primary amyloidosis: colchicine alone, melphalan and prednisone, and melphalan, prednisone, and colchicine. N Engl J Med 336:12021207. doi:10.1056/NEJM199704243361702

2. Comenzo RL, Gertz MA (2002) Autologous stem cell transplantation for primary systemic amyloidosis. Blood 99:4276-4282. doi:10.1182/blood.V99.12.4276

3. Sanchorawala V, Skinner M, Quillen K, Finn KT, Doros G, Seldin DC (2007) Long-term outcome of patients with al amyloidosis treated with high-dose melphalan and stem-cell transplantation. Blood 110:3561-3563. doi:10.1182/blood-2007-07-099481

4. Skinner M, Sanchorawala V, Seldin DC, Dember LM, Falk RH, Berk JL, Anderson JJ, O'Hara C, Finn KT, Libbey CA, Wiesman J, Quillen K, Swan N, Wright DG (2004) High-dose melphalan and autologous stem-cell transplantation in patients with al amyloidosis: an 8-year study. Ann Intern Med 140:85-93

5. Gertz MA, Lacy MQ, Dispenzieri A, Gastineau DA, Chen MG, Ansell SM, Inwards DJ, Micallef IN, Tefferi A, Litzow MR (2002) Stem cell transplantation for the management of primary systemic amyloidosis. Am J Med 113:549-555. doi:10.1016/S0002-9343(02) $01208-1$

6. Dispenzieri A, Kyle RA, Lacy MQ, Therneau TM, Larson DR, Plevak MF, Rajkumar SV, Fonseca R, Greipp PR, Witzig TE, Lust JA, Zeldenrust SR, Snow DS, Hayman SR, Litzow MR, Gastineau DA, Tefferi A, Inwards DJ, Micallef IN, Ansell SM, Porrata LF, Elliott MA, Gertz MA (2004) Superior survival in primary systemic amyloidosis patients undergoing peripheral blood stem cell transplantation: a case-control study. Blood 103:3960-3963. doi:10.1182/blood-2003-12-4192

7. Seldin DC, Anderson JJ, Sanchorawala V, Malek K, Wright DG, Quillen K, Finn KT, Berk JL, Dember LM, Falk RH, Skinner M (2004) Improvement in quality of life of patients with al amyloidosis treated with high-dose melphalan and autologous stem cell transplantation. Blood 104:1888-1893. doi:10.1182/ blood-2004-01-0089

8. Comenzo RL, Vosburgh E, Falk RH, Sanchorawala V, Reisinger J, Dubrey S, Dember LM, Berk JL, Akpek G, LaValley M, O'Hara C, Arkin CF, Wright DG, Skinner M (1998) Dose-intensive melphalan with blood stem-cell support for the treatment of al (amyloid light-chain) amyloidosis: survival and responses in 25 patients. Blood 91:3662-3670

9. Jaccard A, Moreau P, Leblond V, Leleu X, Benboubker L, Hermine O, Recher C, Asli B, Lioure B, Royer B, Jardin F, Bridoux F, Grosbois B, Jaubert J, Piette JC, Ronco P, Quet F, Cogne M, Fermand JP (2007) High-dose melphalan versus melphalan plus dexamethasone for al amyloidosis. $\mathrm{N}$ Engl $\mathrm{J}$ Med 357:1083-1093. doi:10.1056/NEJMoa070484

10. Cohen AD, Zhou P, Chou J, Teruya-Feldstein J, Reich L, Hassoun H, Levine B, Filippa DA, Riedel E, Kewalramani T, Stubblefield MD, Fleisher M, Nimer S, Comenzo RL (2007) Risk-adapted autologous stem cell transplantation with adjuvant dexamethasone $+/-$ thalidomide for systemic light-chain amyloidosis: results of a phase ii trial. Br J Haematol 139:224-233. doi:10.1111/j.1365-2141.2007.06783.x

11. Gertz MA, Comenzo R, Falk RH, Fermand JP, Hazenberg BP, Hawkins PN, Merlini G, Moreau P, Ronco P, Sanchorawala V, Sezer O, Solomon A, Grateau G (2005) Definition of organ involvement and treatment response in immunoglobulin light chain amyloidosis (al): a consensus opinion from the 10th international symposium on amyloid and amyloidosis, tours, France, 18-22 april 2004. Am J Hematol 79:319-328. doi:10.1002/ajh.20381

12. Perz JB, Rahemtulla A, Giles C, Szydlo RM, Davis J, Gopaul D, Gillmore J, Mathias CJ, Hawkins PN, Apperley JF (2006) Longterm outcome of high-dose melphalan and autologous stem cell transplantation for al amyloidosis. Bone Marrow Transplant 37:937-943. doi:10.1038/sj.bmt.1705354

13. Dispenzieri A, Gertz MA, Kyle RA, Lacy MQ, Burritt MF, Therneau TM, McConnell JP, Litzow MR, Gastineau DA, Tefferi A, Inwards DJ, Micallef IN, Ansell SM, Porrata LF, Elliott MA, 
Hogan WJ, Rajkumar SV, Fonseca R, Greipp PR, Witzig TE, Lust JA, Zeldenrust SR, Snow DS, Hayman SR, McGregor CG, Jaffe AS (2004) Prognostication of survival using cardiac troponins and n-terminal pro-brain natriuretic peptide in patients with primary systemic amyloidosis undergoing peripheral blood stem cell transplantation. Blood 104:1881-1887. doi:10.1182/blood-200401-0390

14. Perfetti V, Siena S, Palladini G, Bregni M, Di Nicola M, Obici L, Magni M, Brunetti L, Gianni AM, Merlini G (2006) Long-term results of a risk-adapted approach to melphalan conditioning in autologous peripheral blood stem cell transplantation for primary (al) amyloidosis. Haematologica 91:1635-1643

15. Fadia A, Casserly LF, Sanchorawala V, Seldin DC, Wright DG, Skinner M, Dember LM (2003) Incidence and outcome of acute renal failure complicating autologous stem cell transplantation for al amyloidosis. Kidney Int 63:1868-1873. doi:10.1046/j.15231755.2003.00936.x

16. Dember LM, Sanchorawala V, Seldin DC, Wright DG, LaValley M, Berk JL, Falk RH, Skinner M (2001) Effect of dose-intensive intravenous melphalan and autologous blood stem-cell transplantation on al amyloidosis-associated renal disease. Ann Intern Med 134:746-753

17. Sanchorawala V, Wright DG, Seldin DC, Falk RH, Finn KT, Dember LM, Berk JL, Quillen K, Anderson JJ, Comenzo RL, Skinner M (2004) High-dose intravenous melphalan and autologous stem cell transplantation as initial therapy or following two cycles of oral chemotherapy for the treatment of al amyloidosis: results of a prospective randomized trial. Bone Marrow Transplant 33:381-388. doi:10.1038/sj.bmt.1704346

18. Dispenzieri A, Lacy MQ, Katzmann JA, Rajkumar SV, Abraham RS, Hayman SR, Kumar SK, Clark R, Kyle RA, Litzow MR,
Inwards DJ, Ansell SM, Micallef IM, Porrata LF, Elliott MA, Johnston PB, Greipp PR, Witzig TE, Zeldenrust SR, Russell SJ, Gastineau D, Gertz MA (2006) Absolute values of immunoglobulin free light chains are prognostic in patients with primary systemic amyloidosis undergoing peripheral blood stem cell transplantation. Blood 107:3378-3383. doi:10.1182/blood-2005-07-2922

19. Leung N, Dispenzieri A, Lacy MQ, Kumar SK, Hayman SR, Fervenza FC, Cha SS, Gertz MA (2007) Severity of baseline proteinuria predicts renal response in immunoglobulin light chainassociated amyloidosis after autologous stem cell transplantation. Clin J Am Soc Nephrol 2:440-444. doi:10.2215/CJN.02450706

20. Wechalekar AD, Lachmann HJ, Offer M, Hawkins PN, Gillmore JD (2008) Efficacy of bortezomib in systemic al amyloidosis with relapsed/refractory clonal disease. Haematologica 93:295-298. doi:10.3324/haematol.11627

21. Wechalekar AD, Goodman HJ, Lachmann HJ, Offer M, Hawkins PN, Gillmore JD (2007) Safety and efficacy of risk-adapted cyclophosphamide, thalidomide, and dexamethasone in systemic al amyloidosis. Blood 109:457-464. doi:10.1182/blood-2006-07035352

22. Dispenzieri A, Lacy MQ, Zeldenrust SR, Hayman SR, Kumar SK, Geyer SM, Lust JA, Allred JB, Witzig TE, Rajkumar SV, Greipp PR, Russell SJ, Kabat B, Gertz MA (2007) The activity of lenalidomide with or without dexamethasone in patients with primary systemic amyloidosis. Blood 109:465-470. doi:10.1182/ blood-2006-07-032987

23. Sanchorawala V, Wright DG, Rosenzweig M, Finn KT, Fennessey S, Zeldis JB, Skinner M, Seldin DC (2007) Lenalidomide and dexamethasone in the treatment of al amyloidosis: results of a phase 2 trial. Blood 109:492-496. doi:10.1182/blood-2006-07030544 